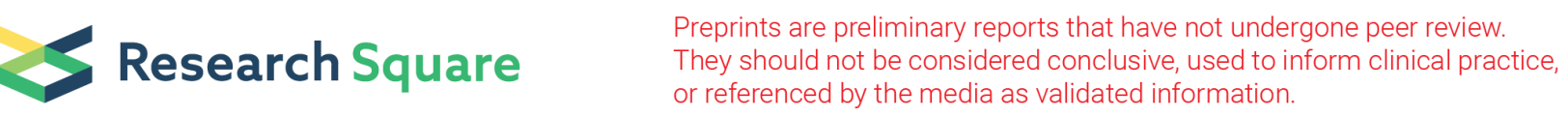

\title{
Systematic Review \& Meta-Analysis of the Diagnostic Accuracy of Prostate Specific Antigen (PSA) for the Detection of Prostate Cancer in Symptomatic Patients
}

\author{
Samuel William David Merriel ( $\nabla$ s.w.d.merriel@exeter.ac.uk) \\ University of Exeter https://orcid.org/0000-0003-2919-9087 \\ Lucy Pocock \\ University of Exeter \\ Emma Gilbert \\ University of Exeter \\ Sam Creavin \\ University of Exeter \\ Fiona M Walter \\ University of Exeter \\ Anne Spencer \\ University of Exeter \\ Willie Hamilton \\ University of Exeter
}

\section{Research Article}

Keywords: Prostate Specific Antigen (PSA), Transrectal Ultrasound guided biopsy (TRUS)

Posted Date: October 21st, 2021

DOI: https://doi.org/10.21203/rs.3.rs-994688/v1

License: (c) (i) This work is licensed under a Creative Commons Attribution 4.0 International License. Read Full License

Version of Record: A version of this preprint was published at BMC Medicine on February 7th, 2022. See the published version at https://doi.org/10.1186/s12916-021-02230-y. 


\section{Abstract}

\section{Background}

Prostate Specific Antigen (PSA) is a commonly used test to detect prostate cancer. Attention has mostly focused on the use of PSA in screening asymptomatic patients, but the diagnostic accuracy of PSA for prostate cancer in patients with symptoms is less well understood.

\section{Methods}

A systematic database search was conducted of Medline, EMBASE, Web of Science, and the Cochrane library. Studies reporting the diagnostic accuracy of PSA for prostate cancer in patients with symptoms were included. Two investigators independently assessed the titles and abstracts of all database search hits and full texts of potentially relevant studies against the inclusion criteria, and data extracted into a proforma. Study quality was assessed using the QUADAS-2 tool by two investigators independently. Summary estimates of diagnostic accuracy were calculated with meta-analysis using bivariate mixed effects regression.

\section{Results}

563 search hits were assessed by title and abstract after de-duplication, with 75 full text papers reviewed. 19 studies met the inclusion criteria, 18 of which were conducted in secondary care settings (one from a screening study cohort). All studies used histology obtained by Transrectal Ultrasound guided biopsy (TRUS) as a reference test, usually only for patients with elevated PSA or abnormal prostate examination. Pooled data from 14,489 patients found estimated sensitivity of PSA for prostate cancer was $0.93(95 \% \mathrm{Cl} 0.88,0.96)$ and specificity was 0.20 (95\% $\mathrm{Cl} 0.12,0.33)$. The area under the receiving-operator characteristic curve was $0.72(95 \% \mathrm{Cl} 0.68,0.76)$. All studies were assessed as having a high risk of bias in at least one QUADAS-2 domain.

\section{Conclusions}

Currently available evidence suggests PSA is highly sensitive but poorly specific for prostate cancer detection. However, significant limitations in study design and reference test reduces the certainty of this estimate. There is very limited evidence for the performance of PSA in primary care, the healthcare setting where most PSA testing is performed.

\section{Introduction}

Prostate specific antigen (PSA) is a commonly used test for the detection of prostate cancer(1). PSA testing is usually performed for one of two reasons: assessing a patient presenting to their GP or primary care physician with lower urinary tract symptoms (LUTS), or opportunistic screening for a patient who is asymptomatic but concerned about their risk of prostate cancer. Patients with an elevated PSA are usually referred to a Urologist for diagnostic testing, which may include magnetic resonance imaging (MRI) of the prostate and/or a prostate biopsy. Very large randomised controlled trials of PSA-based prostate cancer screening have been performed, summarised in a recent systematic review in 2018 that showed a small potential reduction in prostate cancer specific mortality with no change in all-cause mortality and an increased risk of complications from biopsy, overdiagnosis of clinically insignificant prostate cancer, and overtreatment(2). However, uncertainty remains about the diagnostic accuracy of PSA for prostate cancer in patients with LUTS(3).

The most recent systematic review of the diagnostic accuracy of PSA was published by Harvey et al in 2009(4). A range of estimates for the accuracy of PSA was found amongst the ten included studies. That review presented limited information on their methods; crucially, it was unclear whether the included studies were assessing PSA in symptomatic or asymptomatic patients, nor was it clear whether any were relevant to primary care populations. Just et al published a brief review of the literature in 2018, highlighting that the paucity of research in this area applicable to primary care, where a significant proportion of PSA testing is performed, still remains(3). 
This systematic review aimed to determine the diagnostic accuracy of PSA for the detection of prostate cancer in patients, focusing on studies where the included patients (or a subset of included patients) had at least one symptom that could relate to an undiagnosed prostate cancer. Given the findings by Just et al, this review considered studies from primary and secondary care settings.

\section{Methods}

\section{Types of studies}

We included cross-sectional and cohort studies that reported paired data on the diagnostic accuracy of PSA for the detection of prostate cancer in symptomatic men, verified with the use of a reference test (prostate biopsy). We excluded studies if it was not possible to extract data for a complete two-by-two table for the target condition, or if the patient cohort was only asymptomatic patients (i.e. a screening cohort). We did not restrict studies by publication date, country, or clinical setting.

\section{Participants}

The study population of interest was any patient with symptoms of a possible prostate cancer, with no history of the disease. We defined symptoms of prostate cancer as at least one of: LUTS (nocturia, hesitancy, poor stream, incomplete voiding, double voiding, terminal dribbling, urgency, incontinence, frequency), haematuria, erectile dysfunction, or lower back pain. Symptoms may have been identified by a standardised tool, such as the International Prostate Symptom Score (IPSS), clinical coding, or through patient self-report. We did not exclude studies based on age of participants or study setting. Where studies included groups of both asymptomatic and symptomatic men we included men in the symptomatic group.

\section{Index test}

The index test was Prostate Specific Antigen (PSA) in a peripheral blood sample, measured in nanograms per millilitre $(\mathrm{ng} / \mathrm{mL})$. We did not set an a priori abnormal PSA level, but instead extracted data based on the definition of abnormal PSA used in each study.

\section{Target condition}

The target condition was prostate cancer, regardless of Gleason grade or clinicopathological stage.

\section{Reference test}

The reference test was a biopsy of the prostate with histological examination. We did not set an inclusion criteria on the basis of prostate biopsy approach used in studies, but this was recorded as part of the data extraction.

\section{Electronic searches}

Medline Ovid, EMBASE, the Cochrane Central Register of Controlled Trials (CENTRAL) and Web of Science databases were utilised to identify relevant studies. Key search terms, informed by the Scottish Intercollegiate Guidelines Network (SIGN) search strategies and pre-existing systematic reviews in the field of prostate cancer, were combined with MeSH terms for each database search. Hand-searching of reference lists from included studies and snowballing techniques were performed to locate any other possibly relevant studies.

\section{Data collection and analysis}

\section{Selection of studies}

Search hits from each database were downloaded and combined into a review database managed in Mendeley Desktop. Each search hit was screened against the inclusion/exclusion criteria by SM and a 2nd investigator (LP, SC, or EG) independently, based on title and abstract. Full text articles were reviewed if a reviewer was unclear on the basis of title and abstract. Any discrepancies of study inclusion were adjudicated by a third reviewer (WH or AS). 


\section{Data extraction}

A pre-prepared proforma for data extraction was used to collate relevant data from each included study, including two by two tables for the index and reference tests. SM extracted the data from all included studies. A second investigator extracted data from a random sample of $10 \%$ of included studies for verification of accuracy of data extraction. Any discrepancies were adjudicated by a third reviewer (WH or AS).

\section{Quality assessment}

Risk of bias and applicability of all included studies was assessed by SM using the QUADAS-2(5) tool, with a second investigator independently assessing 10\% of included studies and discussed any discrepancies with SM.

\section{Meta-analysis}

Raw data extracted from included papers on PSA result and prostate cancer diagnoses were extracted and combined into $2 \mathrm{x}$ 2 tables to assess diagnostic accuracy. Measures of pooled diagnostic accuracy were determined for the following outcomes using bi-variate mixed effects regression:

Any prostate cancer diagnosis

Clinically significant prostate cancer diagnosis (Gleason Grade Group $\geq 2$ )

The majority of included studies used a fixed PSA threshold of $4 \mathrm{ng} / \mathrm{mL}$, and this was also used as the threshold for metaanalysis. No included studies reported sufficient information to Meta-analyse age-adjusted thresholds.

\section{Heterogeneity}

Heterogeneity was assessed for visually using Forest plots of sensitivity and specificity.

All analyses were performed using Stata Version 16 (StataCorp, http://www.stata.com)

\section{Protocol publication}

The protocol for this systematic review and meta-analysis was registered with PROSPERO (CRD42021257783).

\section{PRISMA reporting guidelines}

This systematic review was conducted following the PRISMA reporting guidelines for systematic reviews and metaanalyses(6).

\section{Results}

Database searching identified 631 potentially relevant studies, and a further 42 studies were identified through reference list checking and snowballing techniques from initial search hits and key papers. Following de-duplication, 563 search hits were assessed by two reviewers independently, and 75 papers selected for full text assessment. 19 papers were ultimately included. Details of full-text exclusions can be found in figure 1 below.

Risk of bias assessment using the QUADAS-2 tool demonstrated a number of potential areas of bias in the included studies (see table 2 and figure 2). None of the studies were assessed as having a low risk of bias with regards to the reference standard test, which was almost always a Transrectal Ultrasound-guided (TRUS) biopsy. TRUS biopsy suffers from a significant risk of false negative or misclassification of prostate cancer diagnosis owing to the random nature of sampling of the prostate(7). The reference standard was performed with knowledge of the index test (PSA) in 16 of 19 studies. Patient populations were drawn from hospital urology clinics in all but one study, affecting applicability to other clinical settings. Limited information with regards to patient selection was available in eight studies, and the majority had a low risk of bias with regards to the conduct of the index test. 
Table 2 - Risk of bias assessment of included studies using QUADAS-2 tool

\begin{tabular}{|c|c|c|c|c|c|c|c|}
\hline \multirow[t]{2}{*}{ Study } & \multicolumn{4}{|c|}{ RISK OF BIAS } & \multicolumn{3}{|c|}{ APPLCABILTYY CONCERNS } \\
\hline & $\begin{array}{l}\text { PATIENT } \\
\text { SELECTION }\end{array}$ & $\begin{array}{c}\text { INDEX } \\
\text { TEST }\end{array}$ & $\begin{array}{l}\text { REFERENCE } \\
\text { STANDARD }\end{array}$ & $\begin{array}{c}\text { FLOW AND } \\
\text { TIMING }\end{array}$ & $\begin{array}{c}\text { PATIENT } \\
\text { SELECTION }\end{array}$ & INDEX TEST & $\begin{array}{l}\text { REFERENCE } \\
\text { STANDARD }\end{array}$ \\
\hline Abdrabo et ol & $?$ & $?$ & (2) & (:) & (:) & (-): & (:) \\
\hline Agnihotri et al & (:) & (:) & (2) & (:) & (:) & (:) & (2) \\
\hline Aragona et ol & (:) & :) & (2) & (2) & (2) & (:) & (2) \\
\hline Chang et al & (:) & ? & (2) & (2) & (:) & ? & (2) \\
\hline Chavan et ol & (:) & (-) & (:) & (:) & (:) & (:) & (2) \\
\hline Galic et of & (:) & (-) & ? & (:) & (-): & (:) & (-) \\
\hline Hofer et ol & : & (:) & (2) & (:) & (:) & (:) & (2) \\
\hline Lee et $a l$ & $?$ & (:) & (2) & (:) & (2) & (:) & : \\
\hline Magistro et ol & $?$ & ? & ? & ? & (:) & $?$ & (:) \\
\hline Meigs et al & $?$ & (:) & (:) & (:) & (2) & (:) & (2) \\
\hline Nordstrom et ol & (:) & (-) & (2) & (:) & (:) & (:) & (2) \\
\hline Patel et ol & ? & (:) & (:) & (:) & (:) & (:) & (2) \\
\hline Pepe et $a l$ & $?$ & (:) & (:) & (:) & (:) & (:) & ? \\
\hline Rashid et of & $?$ & (:) & (2) & (2) & (2) & (:) & (2) \\
\hline Richie et al & (:) & (:): & (2) & (2) & (:) & (:) & (2) \\
\hline Seo et of & (:) & (:) & (:) & (:) & (:) & (:) & (:) \\
\hline Shahab et ol & $?$ & (:) & (2) & (2) & (2) & (:) & (2) \\
\hline Tauro et ol & (:) & (:) & (2) & (:) & (2) & (:) & (2) \\
\hline Wymenga et al & (:) & (:) & (:) & (:) & $?$ & (:) & (:) \\
\hline
\end{tabular}


Table 3

- Details of included studies

\begin{tabular}{|c|c|c|c|c|c|c|c|c|}
\hline $\begin{array}{l}\text { First } \\
\text { Author }\end{array}$ & Year & Country & $\begin{array}{l}\text { Number } \\
\text { of } \\
\text { patients }\end{array}$ & $\begin{array}{l}\text { Mean } \\
\text { age } \\
\text { (range)* }\end{array}$ & Setting & PSA range & $\begin{array}{l}\text { Stage/Grade } \\
\text { data }\end{array}$ & Reference test \\
\hline $\begin{array}{l}\text { Abdrabo } \\
\text { et al (8) }\end{array}$ & 2011 & Sudan & 118 & $\begin{array}{l}70 \\
\text { years } \\
(56- \\
83)\end{array}$ & $\begin{array}{l}\text { One } \\
\text { hospital } \\
\text { urology } \\
\text { clinic }\end{array}$ & $\begin{array}{l}2.5- \\
10 \mathrm{ng} / \mathrm{mL}\end{array}$ & No & TRUS biopsy \\
\hline $\begin{array}{l}\text { Agnihotri } \\
\text { et al (9) }\end{array}$ & 2014 & India & $\begin{array}{l}875 \\
\text { biopsied } \\
\text { (of } 4,702 \\
\text { patients) }\end{array}$ & $\begin{array}{l}66 \\
\text { years } \\
(50- \\
75)\end{array}$ & $\begin{array}{l}\text { One } \\
\text { hospital } \\
\text { urology } \\
\text { clinic }\end{array}$ & Any & No & TRUS biopsy \\
\hline $\begin{array}{l}\text { Aragona } \\
\text { et al (10) }\end{array}$ & 2005 & Italy & $\begin{array}{l}3,171 \\
\text { biopsied } \\
\text { (of } \\
16,298 \\
\text { patients) }\end{array}$ & $\begin{array}{l}62 \\
\text { years } \\
(40- \\
75)\end{array}$ & $\begin{array}{l}15 \text { hospital } \\
\text { urology } \\
\text { clinics }\end{array}$ & Any & $\begin{array}{l}\text { Clinical } \\
\text { TNM } \\
\text { staging }\end{array}$ & TRUS biopsy \\
\hline $\begin{array}{l}\text { Chang et } \\
\text { al(11) }\end{array}$ & 2015 & Taiwan & 225 & $\begin{array}{l}\text { PCa } 72 \\
\text { years; } \\
\text { BPH } 67 \\
\text { years }\end{array}$ & $\begin{array}{l}\text { One } \\
\text { hospital } \\
\text { urology } \\
\text { clinic }\end{array}$ & Any & $\begin{array}{l}\text { TNM stage } \\
\text { and Gleason } \\
\text { Score }\end{array}$ & TRUS biopsy \\
\hline $\begin{array}{l}\text { Chavan et } \\
\text { al (12) }\end{array}$ & 2009 & India & $\begin{array}{l}440 \\
\text { biopsied } \\
\text { (of } 922 \\
\text { patients) }\end{array}$ & $\begin{array}{l}64 \\
\text { years } \\
(40- \\
95)\end{array}$ & $\begin{array}{l}\text { One tertiary } \\
\text { hospital } \\
\text { urology } \\
\text { clinic }\end{array}$ & Any & No & TRUS biopsy \\
\hline $\begin{array}{l}\text { Galic et al } \\
\text { (13) }\end{array}$ & 2003 & Croatia & $\begin{array}{l}88 \\
\text { biopsied } \\
\text { (of } 944 \\
\text { patients) }\end{array}$ & $\begin{array}{l}\geq 50 \\
\text { years }\end{array}$ & $\begin{array}{l}\text { Recruited } \\
\text { from two } \\
\text { villages to } \\
\text { attend } \\
\text { hospital } \\
\text { clinic }\end{array}$ & Not stated & No & TRUS biopsy \\
\hline $\begin{array}{l}\text { Hofer et al } \\
\text { (14) }\end{array}$ & 2000 & Germany & 188 & $\begin{array}{l}\text { PCa } 70 \\
\text { years; } \\
\text { BPH } 68 \\
\text { years }\end{array}$ & $\begin{array}{l}\text { One } \\
\text { hospital } \\
\text { urology } \\
\text { clinic }\end{array}$ & Any & No & $\begin{array}{l}\text { TRUS biopsy / } \\
\text { TURP/ non- } \\
\text { cancer } \\
\text { surgery }\end{array}$ \\
\hline $\begin{array}{l}\text { Lee et al } \\
\text { (15) }\end{array}$ & 2006 & Korea & 201 & $\begin{array}{l}63 \\
\text { years }\end{array}$ & $\begin{array}{l}\text { One } \\
\text { hospital } \\
\text { urology } \\
\text { clinic }\end{array}$ & $<4 \mathrm{ng} / \mathrm{mL}$ & No & TRUS biopsy \\
\hline $\begin{array}{l}\text { Magistro } \\
\text { et al (16) }\end{array}$ & 2020 & Germany & 1,125 & $\begin{array}{l}70 \\
\text { years }\end{array}$ & $\begin{array}{l}\text { One } \\
\text { hospital } \\
\text { urology } \\
\text { clinic }\end{array}$ & Any & $\begin{array}{l}\text { TNM stage } \\
\text { and Gleason } \\
\text { Score }\end{array}$ & $\begin{array}{l}\text { HoLEP (+ } \\
\text { mpMRI with } \\
\text { targeted and } \\
\text { systemic } \\
\text { biopsy for } \\
\text { some } \\
\text { patients) }\end{array}$ \\
\hline $\begin{array}{l}\text { Meigs et } \\
\text { al (17) }\end{array}$ & 1996 & USA & 1,524 & $\begin{array}{l}50-79 \\
\text { years }\end{array}$ & $\begin{array}{l}\text { One } \\
\text { hospital } \\
\text { urology } \\
\text { clinic + two } \\
\text { BPH study } \\
\text { cohorts }\end{array}$ & Any & $\begin{array}{l}\text { Clinical T } \\
\text { stage }\end{array}$ & $\begin{array}{l}\text { TRUS biopsy / } \\
\text { TURP/ non- } \\
\text { cancer } \\
\text { surgery }\end{array}$ \\
\hline $\begin{array}{l}\text { Nordstrom } \\
\text { et al (18) }\end{array}$ & 2021 & Sweden & 1,554 & $\begin{array}{l}64 \\
\text { years } \\
(50- \\
69)\end{array}$ & $\begin{array}{l}\text { Population- } \\
\text { based } \\
\text { screening } \\
\text { study } \\
\text { cohort }\end{array}$ & $>3 \mathrm{ng} / \mathrm{mL}$ & $\begin{array}{l}\text { TNM stage } \\
\text { and Gleason } \\
\text { Score }\end{array}$ & TRUS biopsy \\
\hline
\end{tabular}




\begin{tabular}{|c|c|c|c|c|c|c|c|c|}
\hline $\begin{array}{l}\text { First } \\
\text { Author }\end{array}$ & Year & Country & $\begin{array}{l}\text { Number } \\
\text { of } \\
\text { patients }\end{array}$ & $\begin{array}{l}\text { Mean } \\
\text { age } \\
\text { (range)* }\end{array}$ & Setting & PSA range & $\begin{array}{l}\text { Stage/Grade } \\
\text { data }\end{array}$ & Reference test \\
\hline $\begin{array}{l}\text { Patel et al } \\
\text { (19) }\end{array}$ & 2009 & UK & $\begin{array}{l}647 \\
\text { biopsied } \\
\text { (of } 3,976 \\
\text { patients) }\end{array}$ & $\begin{array}{l}65 \\
\text { years } \\
(15- \\
91)\end{array}$ & $\begin{array}{l}\text { One } \\
\text { hospital } \\
\text { urology } \\
\text { clinic }\end{array}$ & Any & No & TRUS biopsy \\
\hline $\begin{array}{l}\text { Pepe et al } \\
\text { (20) }\end{array}$ & 2007 & Italy & $\begin{array}{l}403 \\
\text { biopsied } \\
\text { (of } \\
13,294 \\
\text { patients) }\end{array}$ & $\begin{array}{l}62 \\
\text { years } \\
(40- \\
75)\end{array}$ & $\begin{array}{l}\text { Two } \\
\text { hospital } \\
\text { urology } \\
\text { clinics }\end{array}$ & $<4 \mathrm{ng} / \mathrm{mL}$ & $\begin{array}{l}\text { Pathological } \\
\text { T stage }\end{array}$ & TRUS biopsy \\
\hline $\begin{array}{l}\text { Rashid et } \\
\text { al (21) }\end{array}$ & 2012 & Bangladesh & 206 & $\begin{array}{l}>50 \\
\text { years }\end{array}$ & $\begin{array}{l}\text { One } \\
\text { hospital } \\
\text { urology } \\
\text { clinic and } \\
\text { one } \\
\text { nursing } \\
\text { home }\end{array}$ & $>2.5 \mathrm{ng} / \mathrm{mL}$ & No & TRUS biopsy \\
\hline $\begin{array}{l}\text { Richie et } \\
\text { al(22) }\end{array}$ & 1993 & USA & $\begin{array}{l}1,167 \\
\text { biopsied } \\
\text { (of } 6,630 \\
\text { patients) }\end{array}$ & $\begin{array}{l}63 \\
\text { years } \\
(50- \\
96)\end{array}$ & $\begin{array}{l}\text { Six } \\
\text { medical } \\
\text { centres }\end{array}$ & Any & $\begin{array}{l}\text { TNM stage } \\
\text { and Gleason } \\
\text { Score }\end{array}$ & TRUS biopsy \\
\hline $\begin{array}{l}\text { Seo et al } \\
(23)\end{array}$ & 2007 & Korea & 4,967 & $\begin{array}{l}66 \\
\text { years } \\
(40- \\
96)\end{array}$ & $\begin{array}{l}25 \text { hospital } \\
\text { urology } \\
\text { clinics }\end{array}$ & Any & No & TRUS biopsy \\
\hline $\begin{array}{l}\text { Shahab et } \\
\text { al (24) }\end{array}$ & 2013 & Indonesia & 404 & $\begin{array}{l}64 \\
\text { years } \\
(34- \\
84)\end{array}$ & $\begin{array}{l}\text { One } \\
\text { hospital } \\
\text { urology } \\
\text { clinic }\end{array}$ & Any & $\begin{array}{l}\text { TNM stage } \\
\text { and Gleason } \\
\text { Score }\end{array}$ & TRUS biopsy \\
\hline $\begin{array}{l}\text { Tauro et al } \\
\text { (25) }\end{array}$ & 2009 & India & 100 & $\begin{array}{l}68 \\
\text { years }\end{array}$ & $\begin{array}{l}\text { One } \\
\text { hospital } \\
\text { urology } \\
\text { clinic }\end{array}$ & Any & No & TRUS biopsy \\
\hline $\begin{array}{l}\text { Wymenga } \\
\text { et al (26) }\end{array}$ & 2000 & $\begin{array}{l}\text { The } \\
\text { Netherlands }\end{array}$ & 716 & $\begin{array}{l}\text { Not } \\
\text { reported }\end{array}$ & $\begin{array}{l}\text { Two } \\
\text { hospital } \\
\text { urology } \\
\text { clinics }\end{array}$ & Any & $\begin{array}{l}\text { Clinical T } \\
\text { stage }\end{array}$ & $\begin{array}{l}\text { TRUS biopsy / } \\
\text { TURP/ } \\
\text { prostatectomy }\end{array}$ \\
\hline
\end{tabular}

PSA - Prostate Specific Antigen; TRUS - Transrectal Ultrasound guided biopsy; PCa - Prostate cancer; BPH - Benign Prostatic Hypertrophy; TNM - Tumour-node-metastasis; TURP - Transurethral resection of the prostate; HoLEP - Holmium laser enucleation of the prostate; $\mathrm{mpMRI}$ - multiparametric magnetic resonance imaging

* Age range and/or mean not present in table if not reported

Table 3 summarises the features of the included studies. There was a wide range of countries and study sizes. One study focused on a symptomatic cohort within a population screening study, and the remainder were set in hospital urology clinics. No study was performed in a primary care population. Five studies gathered stage and grade data. All but one study used TRUS biopsy as a reference test, with three studies also gathering diagnostic data from Transurethral Resection of the Prostate (TURP) or other urological surgical procedures involving the prostate.

Table 4 shows the measures of diagnostic accuracy calculated using reported data in 14 included studies featuring 14,489 patients that considered a PSA level of greater than or equal to $4 \mathrm{ng} / \mathrm{mL}$ as abnormal. The remaining five studies focused on populations in a specific part of the PSA range - either a low or raised PSA level. Meta-analysis showed an estimated combined sensitivity of a PSA greater than or equal to $4 \mathrm{ng} / \mathrm{mL}$ for any prostate cancer of $0.93(95 \% \mathrm{Cl} 0.88,0.96)$ and a 
combined specificity of $0.20(95 \% \mathrm{Cl} 0.12,0.33)$ (See figure 3$)$. There was significant heterogeneity between included studies (sensitivity I 2 98.97, specificity I2 99.61). Receiver Operator Curve (ROC) analysis showed an AUC of $0.72(95 \% \mathrm{Cl} 0.68,0.76)$ (See figure 4).

Three studies included in the meta-analysis collected stage and grade data for prostate cancer cases; however, none of these studies reported data for clinically significant prostate cancer diagnoses at a PSA cut-off of $\geq 4 \mathrm{ng} / \mathrm{mL}$. Chang et al(11) did not report the accuracy of PSA, but showed a statistically significant difference in free:total PSA ratio for a Gleason Score of seven or more compared to Gleason Score of six or lower (11.69+/- 0.98 vs $16.47+/-2.25, p=0.029)$. Richie et al(22) did not report the Gleason Score data collected, but found higher PSA levels and increasing age were associated with a higher risk of metastatic prostate cancer. Shahab et al(24) identified a PSA cut-off of $6.95 \mathrm{ng} / \mathrm{mL}$ for differentiating moderate versus high Gleason Score (which was not defined).

Table 4

- Diagnostic accuracy of PSA $\geq 4 \mathrm{ng} / \mathrm{mL}$ for prostate cancer detection in symptomatic patients

\begin{tabular}{|llllll|}
\hline Author & Year & Sensitivity & Specificity & Positive Predictive Value & Negative Predictive Value \\
\hline Abdrabo & 2011 & 0.92 & 0.24 & 0.35 & 0.87 \\
\hline Agnihotri & 2014 & 0.99 & 0.05 & 0.59 & 0.80 \\
\hline Aragona & 2005 & 0.92 & 0.15 & 0.38 & 0.76 \\
\hline Chang & 2015 & 0.89 & 0.09 & 0.19 & 0.76 \\
\hline Chavan & 2009 & 0.96 & 0.03 & 0.18 & 0.79 \\
\hline Galic & 2003 & 0.91 & 0.32 & 0.47 & 0.85 \\
\hline Hofer & 2000 & 0.92 & 0.29 & 0.46 & 0.85 \\
\hline Meigs & 1996 & 0.61 & 0.74 & 0.34 & 0.89 \\
\hline Rashid & 2012 & 0.72 & 0.46 & 0.28 & 0.85 \\
\hline Richie & 1993 & 0.82 & 0.48 & 0.31 & 0.90 \\
\hline Seo & 2007 & 0.98 & 0.04 & 0.33 & 0.87 \\
\hline Shahab & 2013 & 0.98 & 0.19 & 0.13 & 0.98 \\
\hline Tauro & 2009 & 1.00 & 0.38 & 0.40 & 1 \\
\hline Wymenga & 2000 & 0.95 & 0.16 & 0.44 & 0.82 \\
\hline
\end{tabular}

\section{Discussion}

\section{Summary of findings}

Published studies assessing the diagnostic accuracy of PSA in symptomatic patients reported high sensitivity and low specificity for the detection of prostate cancer. 18 of the 19 included studies were undertaken in hospital urology outpatient populations, with one study focused on a symptomatic cohort within a population screening study. Importantly, there were no studies assessing the performance of PSA in a primary care population. Insufficient data was available to assess the diagnostic accuracy of PSA for clinically significant prostate cancer. Furthermore, all included studies had a high risk of bias in at least one QUADAS domain. 


\section{Comparison to existing literature}

Harvey et al(4) published a systematic review of the diagnostic accuracy of PSA for prostate cancer in European populations, focused on studies published between 1998 and 2008. Individual study level data from 10 included papers was reported, though without estimating a combined level of accuracy. They considered the accuracy of PSA for all prostate cancer types overall, and showed a range of accuracy estimates similar to this study. Over half of the studies included in this review were published since the review by Harvey et al. A review of clinical features of prostate cancer in primary care by Young and colleagues(27) in 2015 identified one study from 1989 of 287 patients referred from primary care with bladder outlet obstruction, of whom 211 had a PSA test. High levels of sensitivity (89.5\%) and specificity (90\%) were reported, but Young and colleagues considered the true level of accuracy was likely to be lower given few patients with a normal PSA level had the reference test for prostate cancer.

\section{Strengths \& weaknesses}

This study benefited from a rigorous, focused, methodological approach in conducting the review. All clinical settings were eligible, ensuring we found as many relevant studies as possible. Most included studies employed PSA in a similar manner, using similar indications and diagnostic thresholds, allowing for cross-study comparisons.

The evidence for the association between lower urinary tract symptoms and prostate cancer, in particularly clinically significant prostate cancer, is equivocal. A number of secondary care studies suggest that symptoms do not discriminate well between prostate cancer and benign prostatic hypertrophy $(28,29)$. This assumption is largely untested in primary care populations, and contrasts with studies showing that the majority of patients diagnosed with prostate cancer present to their GP with LUTS prior to diagnosis(30-33). This controversy also means that LUTS and other relevant symptoms may not be reported or be the focus of some potentially relevant studies of PSA for prostate cancer, and may have limited the sensitivity of the search strategy employed. However, key papers were picked up by the database searches and the majority of PSA studies will likely be focused on screening in asymptomatic populations.

All included studies employed TRUS biopsy as a reference test, with some also including pathological data obtained from urological procedures on the prostate. TRUS biopsy is recognised as having poor sensitivity as a diagnostic test(34), owing to the inability to visualise lesions within the prostate resulting in a random sampling of the gland, and thus misclassification bias. Most included studies only performed the reference test on patients with a raised PSA or abnormal prostate examination, introducing partial verification bias. Therefore, the true sensitivity of PSA in symptomatic patients is unknown and likely to be lower than reported.

\section{Implications for research \& practice}

PSA is a commonly used test to assess for the presence of prostate cancer, mostly in a primary care setting, and is recommended as part of the assessment of patients with LUTS in national guidelines(35-37). The lack of primary care evidence for the use of PSA to detect prostate cancer is known, and is not the only condition for which secondary care evidence has been applied to primary care guidance(38). Even so, this is a major gap in knowledge, as spectrum bias means that secondary care data (or screening data) do not translate to primary care. High quality studies in primary care populations are needed to fill this gap, and future studies should report not just on prostate cancer per se, but on clinically significant cancer as well. The introduction of more accurate diagnostic tests for prostate cancer, including multiparametric magnetic resonance imaging (34), increases the need for better understanding of the role of PSA in the early detection of symptomatic prostate cancer.

Primary care clinicians are generally aware of the limitations of PSA testing(39), and clinical guidelines encourage a balanced discussion with patients of the potential benefits and harms of relying on PSA to detect prostate cancer( $(40,41)$. The findings of this review suggest this is a pragmatic approach in providing care to patients with LUTS. Alternative tests to PSA have been extensively researched $(42,43)$, and some show promise of improving the level of confidence in detecting prostate cancer, though none has entered primary care practice as yet. 


\section{Conclusions}

Published evidence from almost entirely secondary care based studies suggests that PSA has high sensitivity and low specificity for the diagnosis of prostate cancer in symptomatic patients. Published studies suffer from a number of biases, which probably overestimate the accuracy of PSA, and there were no included studies assessing the accuracy of PSA in a primary care population. The utility of PSA for the diagnosis of clinically significant prostate cancer in primary care remains unclear and needs urgent study. A major focus of such a study would be to identify patients with clinically significant cancer, warranting radical treatments, whilst avoiding exacerbating the issue of overdiagnosis of clinically insignificant prostate cancer.

\section{Declarations}

Conflict of interest statement - all authors confirm they have no relevant conflicts of interest to declare.

Funding - This research arises from the CanTest Collaborative, which is funded by Cancer Research UK [C8640/A23385], of which SM is a Clinical Research Fellow, AS is an Associate Director, and FMW and WH are co-Directors. SC and LP are funded by the National Institute for Health Research (NIHR). The views expressed are those of the author(s) and not necessarily those of the NIHR or the Department of Health and Social Care.

\section{References}

1. Young GJ, Harrison S, Turner EL, Walsh El, Oliver SE, Ben-Shlomo Y, et al. Prostate-specific antigen (PSA) testing of men in UK general practice: A 10-year longitudinal cohort study. BMJ Open. 2017;7(10).

2. Ilic D, Djulbegovic M, Jung JH, Hwang EC, Zhou Q, Cleves A, et al. Prostate cancer screening with prostate-specific antigen (PSA) test: a systematic review and meta-analysis. BMJ [Internet]. 2018;362:k3519. Available from: http://www.ncbi.nlm.nih.gov/pubmed/30185521.

3. Just J, Osgun F, Knight C. Lower urinary tract symptoms and prostate cancer: is PSA testing in men with symptoms wise? Br J Gen Pract [Internet]. 2018 Nov;68(676):541-2. Available from: http://bjgp.org/lookup/doi/10.3399/bjgp18X699689.

4. Harvey P, Basuita A, Endersby D, Curtis B, lacovidou A, Walker M. A systematic review of the diagnostic accuracy of prostate specific antigen. BMC Urol. 2009;9(1):1-9.

5. Whiting PF, Rutjes AWS, Westwood ME, Mallet S, Deeks JJ, Reitsma JB, et al. QUADAS-2: A Revised Tool for the Quality Assessment of Diagnostic Accuracy Studies. Ann Intern Med. 2011;155(4):529-36.

6. Liberati A, Altman DG, Tetzlaff J, Mulrow C, Gøtzsche PC, loannidis JPA, et al. The PRISMA statement for reporting systematic reviews and meta-analyses of studies that evaluate health care interventions: explanation and elaboration. PLoS Med. 2009;6(7):e1000100.

7. Drost FJ, Osses DF, Nieboer D, Bangma CH, Steyerberg EW, Roobol MJ, et al. Prostate MRI, with or without targeted biopsy and standard biopsy for detecting prostate cancer: A Cochrane systematic review and meta-analysis. Cochrane Database Syst Rev. 2019;(4):CD012663.

8. Abdrabo AA, Fadlalla Al, Fadl-Elmula IM. Significance of serum total prostate specific antigen and digital rectal examination in the diagnosis of prostate cancer. Saudi Med J [Internet]. 2011;32(11):1133-6. Available from: http://ovidsp.ovid.com/ovidweb.cgi?T=JS\&PAGE=reference\&D=med8\&NEWS=N\&AN=22057600.

9. Agnihotri S, Mittal RD, Kapoor R, Mandhani A. Raising cut-off value of prostate specific antigen (PSA) for biopsy in symptomatic men in India to reduce unnecessary biopsy. Indian J Med Res [Internet]. 2014;139(6):851-6. Available from: http://ovidsp.ovid.com/ovidweb.cgi?T=JS\&PAGE=reference\&D=med11\&NEWS=N\&AN=25109719.

10. Aragona F, Pepe P, Motta M, Saita A, Raciti G, La Rosa P, et al. Incidence of prostate cancer in Sicily: Results of a multicenter case-findings protocol. Eur Urol. 2005;47(5):569-74. 
11. Chang C-C, Lee Y-C, Tsai H-W, Yii S-C, Yen T-H, Chu F-Y. Diagnostic Role of Serum Free-to-Total Prostate Specific Antigen (PSA) Ratio in Prostate Cancer with Serum Total Concentration of PSA below $4 \mathrm{ng} / \mathrm{mL}$. Asian Pac J Cancer Prev [Internet]. 2015;16(13):5261-4. Available from: http://ovidsp.ovid.com/ovidweb.cgi?

$\mathrm{T}=\mathrm{JS} \& \mathrm{PAGE}=$ reference\&D=med12\&NEWS=N\&AN=26225663.

12. Chavan PR, Chavan VS, Chavan NR, Trivedi VD. Detection rate of prostate cancer using prostate specific antigen in patients presenting with lower urinary tract symptoms: A retrospective study. J Postgrad Med. 2009;55(1):17-21.

13. Galic J, Karner I, Cenan L, Tucak A, Hegedus I, Pasini J, et al. Comparison of Digital Rectal Examination and Prostate Specific Antigen in Early Detection of Prostate Cancer. Coll Antropol. 2003;27(S1):61-6.

14. Hofer C, Sauerstein P, Wolter C, Scholz M, Hartung R, Breul J. Value of free prostate-specific antigen (Hybritech Tandem-R) in symptomatic patients consulting the urologist. Urol Int. 2000;64(1):18-23.

15. Lee SW, Byun SS, Lee SE. The Diagnostic Significance of Abnormal Findings on Transrectal Ultrasonography in Patients with Serum Prostate-Specific Antigen Levels Equal or Less than 4.0ng/ml. Korean J Urol [Internet]. 2006;47(7):752. Available from: http://ovidsp.ovid.com/ovidweb.cgi?T=JS\&PAGE=reference\&D=emed9\&NEWS=N\&AN=44613335.

16. Magistro G, Keller P, Westhofen T, Schott M, Tamalunas A, Weinhold P, et al. The significance of a high preoperative PSA level for the detection of incidental prostate cancer in LUTS patients with large prostates. World J Urol [Internet]. 2020; Available from: http://ovidsp.ovid.com/ovidweb.cgi?T=JS\&PAGE=reference\&D=medp\&NEWS=N\&AN=32588205.

17. Meigs JB, Barry MJ, Oesterling JE, Jacobsen SJ. Interpreting results of prostate-specific antigen testing for early detection of prostate cancer. J Gen Intern Med [Internet]. 1996;11(9):505-12. Available from: http://ovidsp.ovid.com/ovidweb.cgi? $\mathrm{T}=\mathrm{JS} \& \mathrm{PAGE}=$ reference\&D$=$ med4\&NEWS $=\mathrm{N} \& A N=8905498$.

18. Nordström T, Engel JC, Bergman M, Egevad L, Aly M, Eklund M, et al. Identifying Prostate Cancer Among Men with Lower Urinary Tract Symptoms. Eur Urol Open Sci. 2021;24:11-6.

19. Patel NS, Blick C, Kumar PVS, Malone PR. The diagnostic value of abdominal ultrasound, urine cytology and prostatespecific antigen testing in the lower urinary tract symptoms clinic. Int J Clin Pract [Internet]. 2009;63(12):1734-8. Available from: http://ovidsp.ovid.com/ovidweb.cgi?T=JS\&PAGE=reference\&D=med7\&NEWS=N\&AN=19930334.

20. Pepe P, Panella P, Savoca F, Cacciola A, D’Arrigo L, Dibenedetto G, et al. Prevalence and clinical significance of prostate cancer among 12,682 men with normal digital rectal examination, low PSA levels ( $<=4 \mathrm{ng} / \mathrm{ml}$ ) and percent free PSA cutoff values of 15 and 20\%. Urol Int. 2007;78(4):308-12.

21. Rashid MM, Alam AKMK, Habib AKMK, Rahman H, Hossain AKMS, Salam MA, et al. Efficacy of lower cut off value of serum prostate specific antigen in diagnosis of prostate cancer. Bangladesh Med Res Counc Bull [Internet].

2012;38(3):90-3. Available from: http://ovidsp.ovid.com/ovidweb.cgi?

$\mathrm{T}=\mathrm{JS} \& P A G E=$ reference\&D=med9\&NEWS=N\&AN=23540183.

22. Richie JP, Catalona WJ, Ahmann FR, Hudson MA, Scardino PT, Flanigan RC, et al. Effect of patient age on early detection of prostate cancer with serum prostate-specific antigen and digital rectal examination. Urology. 1993;42(4):365-74.

23. Seo HK, Chung MK, Ryu SB, Lee KH, Oncologic U, Prostate S, et al. Detection Rate of Prostate Cancer According to Prostate-Specific Antigen and Digital Rectal Examination in Korean Men: A Nationwide Multicenter Study. J Urol. 2007;70(6):1109-12.

24. Shahab AA, Soebadi DM, Djatisoesanto W, Hardjowijoto S, Soetojo S, Hakim L. Prostate-specific antigen and prostatespecific antigen density cutoff points among Indonesian population suspected for prostate cancer. Prostate Int [Internet]. 2013;1(1):23-30. Available from: http://dx.doi.org/10.12954/PI.12003.

25. Tauro LF, Rao K, Shetty M, Rao BSS, Shenoy DH. Significance of prostate specific antigen and prostate volume in the diagnosis of prostatic diseases. J Clin Diagnostic Res [Internet]. 2009;3(1):1274-84. Available from: http://www.jcdr.net/articles/PDF/442/355.pdf.

26. Wymenga LFA, Duisterwinkel FJ, Groenier K, Visser-van Brummen P, Marrink J, Mensink HJA. Clinical implications of freeto-total immunoreactive prostate-specific antigen ratios. Scand J Urol Nephrol. 2000;34(3):181-7. 
27. Young S-M, Bansal P, Vella ET, Finelli A, Levitt C, Loblaw A. Systematic review of clinical features of suspected prostate cancer in primary care. Can Fam Physician [Internet]. 2015;61(1):e26-35. Available from:

http://ovidsp.ovid.com/ovidweb.cgi?T=JS\&PAGE=reference\&D=med12\&NEWS=N\&AN=25756146.

28. Bhindi A, Bhindi B, Kulkarni GS, Hamilton RJ, Toi A, van der Kwast TH, et al. Modern-day prostate cancer is not meaningfully associated with lower urinary tract symptoms: Analysis of a propensity score-matched cohort. J Can Urol Assoc. 2017;11(1-2February):41-6.

29. Cicione A, Cormio L, Cantiello F, Palumbo IM, De Nunzio C, Lima E, et al. Presence and severity of lower urinary tract symptoms are inversely correlated with the risk of prostate cancer on prostate biopsy. Minerva Urol e Nefrol. 2017;69(5):486-92.

30. Østerø i Jákupsstovu J, Brodersen J. Do men with lower urinary tract symptoms have an increased risk of advanced prostate cancer? BMJ [Internet]. 2018;361(1202):1-6. Available from: https://www.bmj.com/content/bmj/361/bmj.k1202.full.pdf.

31. Donnelly DW, Vis LC, Kearney T, Sharp L, Bennett D, Wilding S, et al. Quality of life among symptomatic compared to PSAdetected prostate cancer survivors-results from a UK wide patient-reported outcomes study. BMC Cancer. 2019;19(1).

32. Hamilton W, Sharp DJ, Peters TJ, Round AP. Clinical features of prostate cancer before diagnosis: a population-based, case-control study. Br J Gen Pract [Internet]. 2006;56(531):756-62. Available from:

http://www.pubmedcentral.nih.gov/articlerender.fcgi?artid=1920715\&tool=pmcentrez\&rendertype=abstract.

33. Barrett J, Hamilton W. Pathways to the diagnosis of prostate cancer in a British city. A population-based study. Scand J Urol Nephrol [Internet]. 2005;39(4):267-70. Available from: http://ovidsp.ovid.com/ovidweb.cgi?

$T=J S \& P A G E=$ reference\&D=med6\&NEWS=N\&AN=16118101.

34. Ahmed HU, Bosaily AE-S, Brown LC, Gabe R, Kaplan R, Parmar MK, et al. Diagnostic accuracy of multi-parametric MRI and TRUS biopsy in prostate cancer (PROMIS): a paired validating confirmatory study. Lancet [Internet]. 2017 Jan 19;380:18. Available from: http://dx.doi.org/10.1016/S0140-6736(16)32401-1.

35. National Collaborating Centre for Cancer. Suspected cancer [Internet]. NICE. London. 2015. Available from: http://journals.rcni.com/doi/10.7748/ns.29.47.17.s20.

36. Mottet N, Bellmunt J, Briers E, Bolla M, Bourke L, Cornford P, et al. EAU - ESTRO - ESUR - SIOG Guidelines on Prostate Cancer [Internet]. European Association of Urology; 2017. Available from: https://uroweb.org/wp-content/uploads/09Prostate-Cancer_2017_web.pdf.

37. Carter B, Albertsen P, Barry M, Etzioni R, Freedland S, Greene K, et al. Early Detection of Prostate Cancer: Aua Guideline. American Urological Association Education and Research; 2018. pp. 1-28.

38. Funston G, Hamilton W, Abel G, Crosbie E, Rous B, Walter F. The diagnostic performance of CA125 for the detection of ovarian and non-ovarian cancer in primary care: a population-based cohort study. PLoS Med. 2020;17(10):e1003295.

39. Evans R, Edwards AGK, Elwyn G, Watson E, Grol R, Brett J, et al. It's a maybe test': men's experiences of prostate specific antigen testing in primary care. Br J Gen Pract [Internet]. 2007 Apr 1;57(537):303-10. Available from:

http://www.ncbi.nlm.nih.gov/pubmed/17394734?

ordinalpos=25\&itool=EntrezSystem2.PEntrez.Pubmed.Pubmed_ResultsPanel.Pubmed_RVDocSum.

40. Roland M, Neal D, Buckley R. What should doctors say to men asking for a PSA test? Bmj [Internet]. 2018;3702(September):k3702. Available from: http://www.bmj.com/lookup/doi/10.1136/bmj.k3702.

41. Public Health England. Prostate Cancer Risk Management Programme (PCRMP): benefits and risks of PSA testing [Internet]. PCRMP. 2016 [cited 2018 Nov 6]. Available from: https://www.gov.uk/government/publications/prostatecancer-risk-management-programme-psa-test-benefits-and-risks/prostate-cancer-risk-management-programme-pcrmpbenefits-and-risks-of-psa-testing.

42. Eldred-Evans D, Burak P, Connor M, Day E, Evans M, Fiorentino F, et al. Population-based prostate cancer screening with Magnetic Resonance or Ultrasound Imaging: The IP1-PROSTAGRAM study. JAMA Oncol. 2021;1-7. 
43. Kim L, Boxall N, George A, Burling K, Acher P, Aning J, et al. Clinical utility and cost modelling of the phi test to triage referrals into image-based diagnostic services for suspected prostate cancer: the PRIM (Phi to RefIne Mri) study. BMC Med [Internet]. 2020 Dec 17;18(1):95. Available from: http://ovidsp.ovid.com/ovidweb.cgi?

$T=J S \& P A G E=r e f e r e n c e \& D=e m e x b \& N E W S=N \& A N=631540618$.

\section{Tables}

Table 1 is not available with this version.

\section{Figures}

PRISMA 2020 flow diagram for new systematic reviews which included searches of databases and registers only

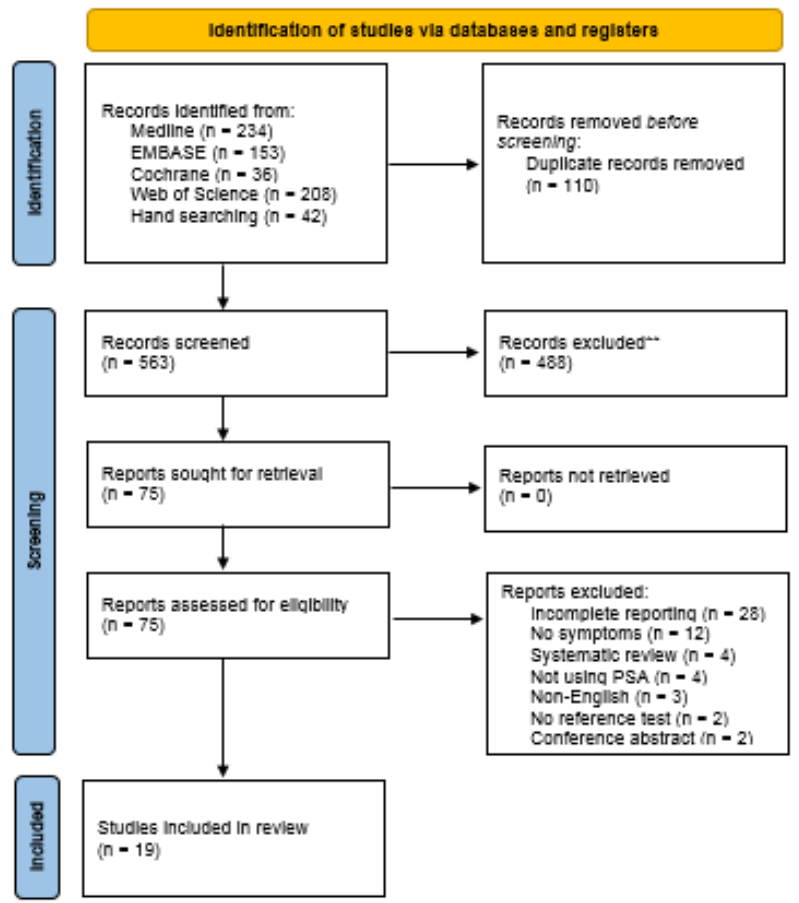

From: Page MJ, McKenzle JE, Bossuyt PM, Boutron I, Hottmann TC, Mulrow CD, et al. The PRISMA 2020 statement: an updated quidelline for reporting systematic review5. BMJ 2021;372:n71. dol: 10.1136/bml.n71

\section{Figure 1}

PRISMA 2020 flow diagram
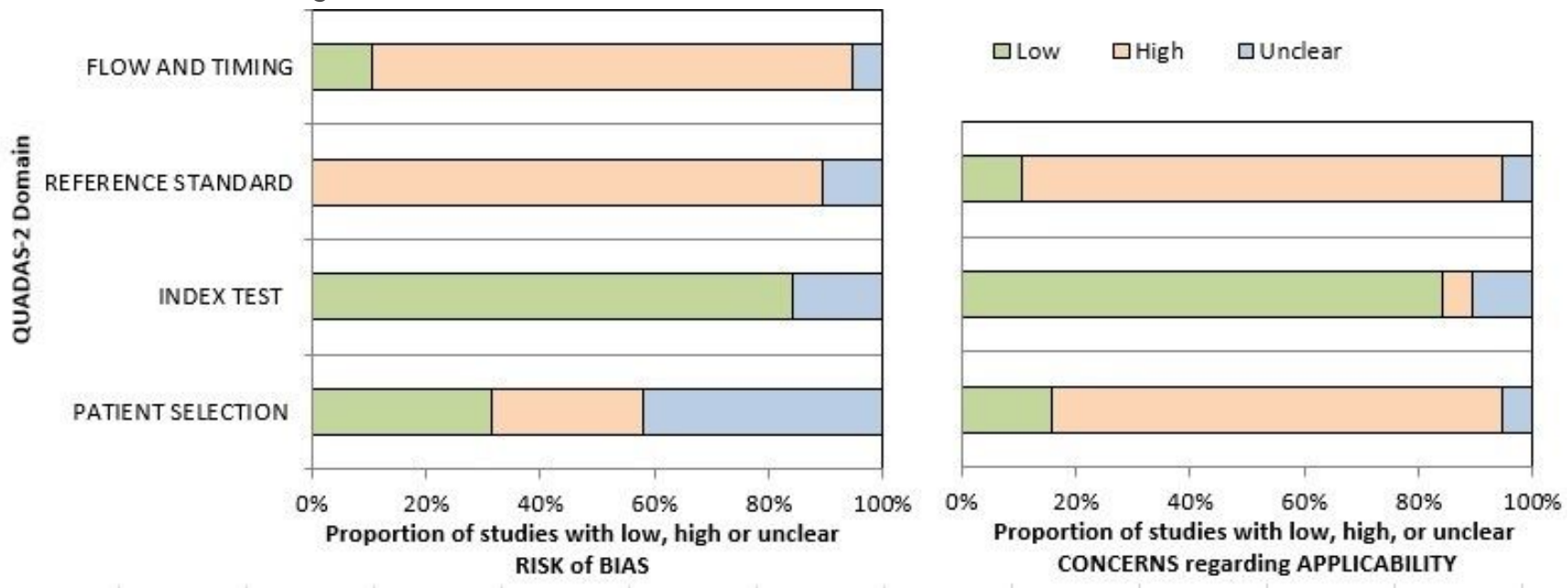


\section{Figure 2}

Summary of QUADAS-2 risk of bias assessments

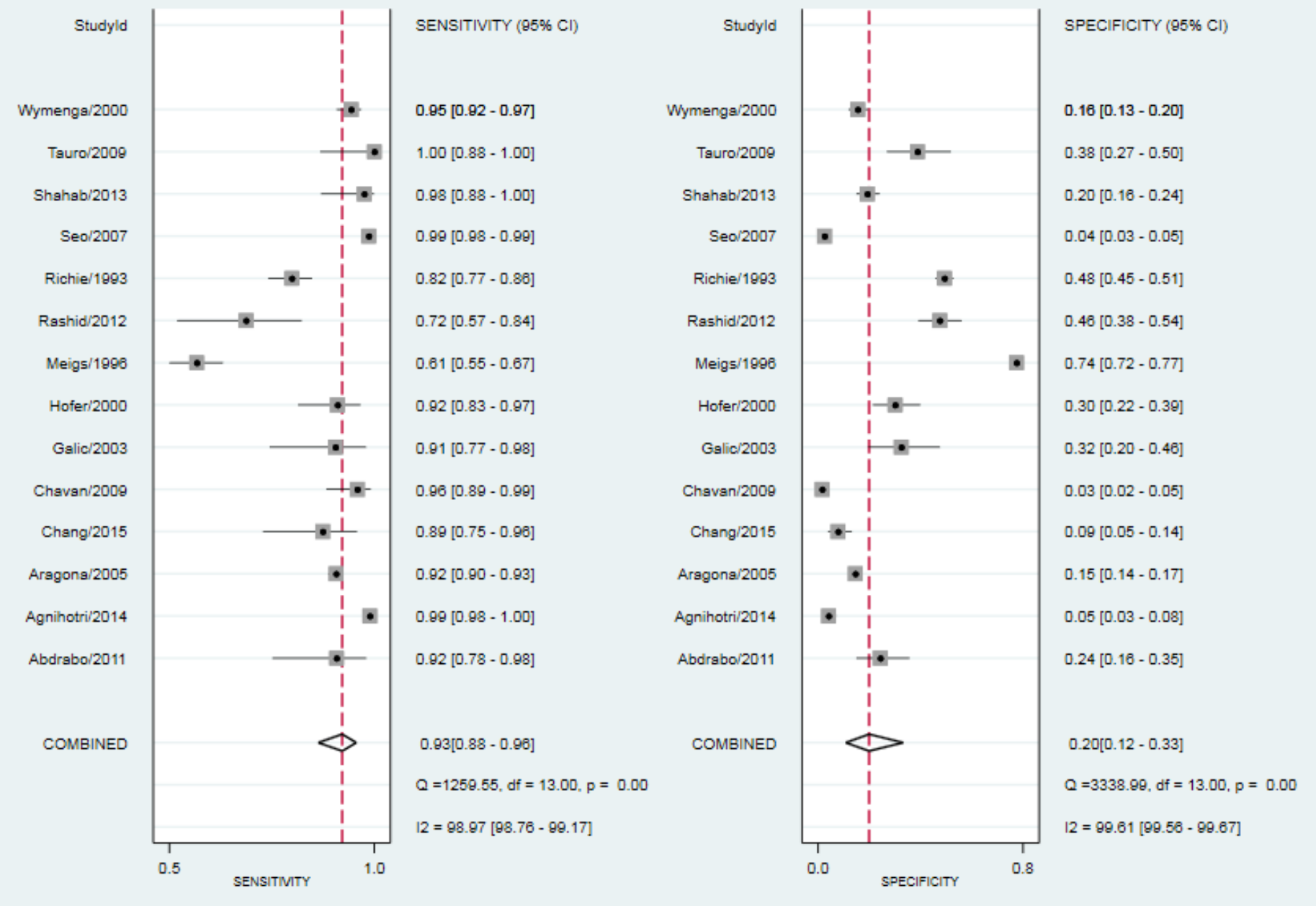

\section{Figure 3}

Forest plot of included studies using PSA cut-off of $4 \mathrm{ng} / \mathrm{mL}$ 


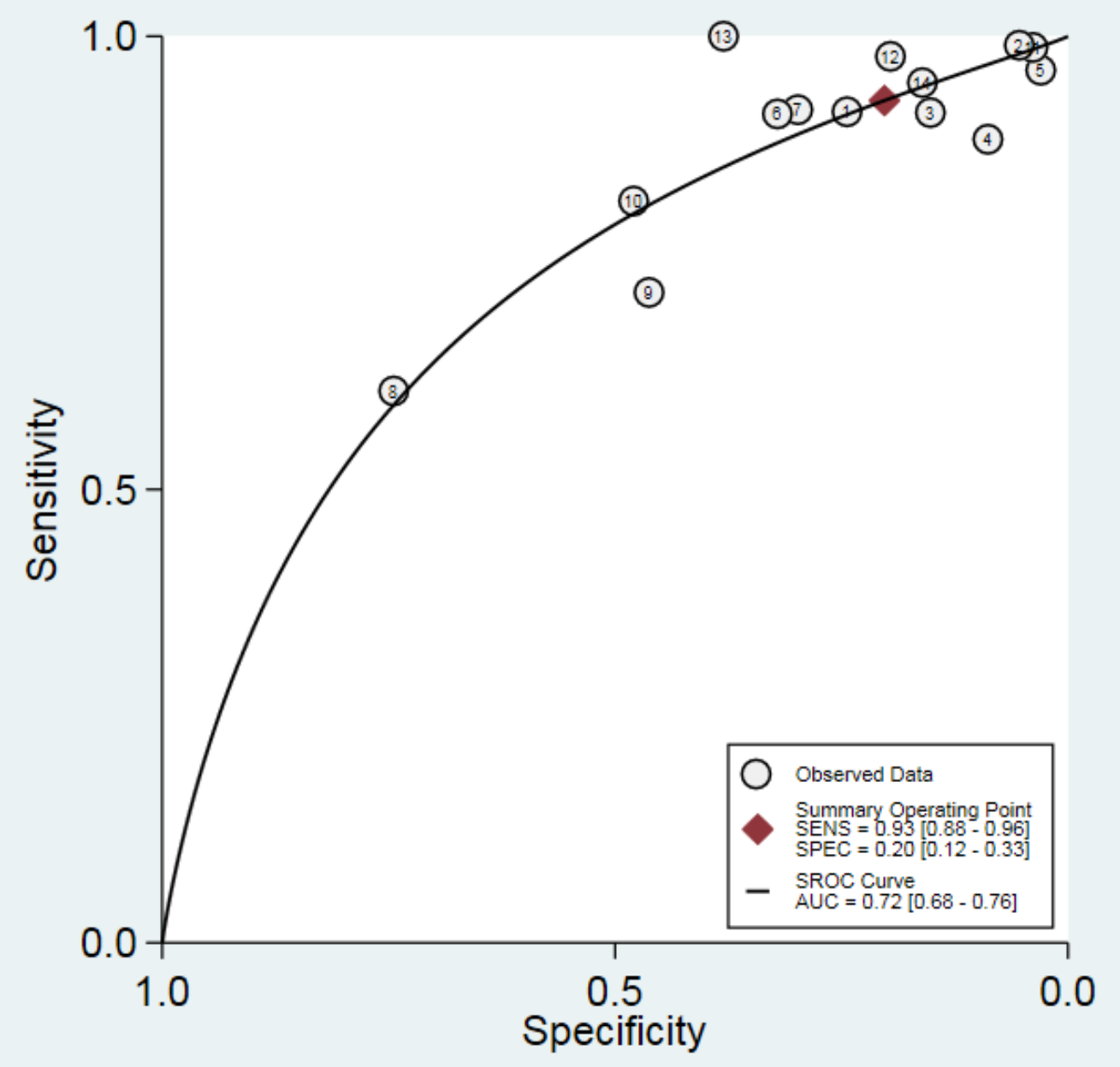

Figure 4

Receiver Operator Curve (ROC) of included studies using PSA cut-off of $4 \mathrm{ng} / \mathrm{mL}$

\section{Supplementary Files}

This is a list of supplementary files associated with this preprint. Click to download.

- SupplementaryFiles.docx

- PRISMA2020checklistPSA.docx 